\title{
PROOF-THEORETICAL SEMANTICS AND FREGEAN IDENTITY CRITERIA FOR PROPOSITIONS*
}

In his Grundgesetze, §32, Frege launched the idea that the meaning of a sentence is given by its truth condition, or, in his particular version, the condition under which it will be a name of the True. This, indeed, was only one of the many roles in which truth has to serve within the Fregean system. In particular, truth is an absolute notion in the sense that bivalence holds: every Gedanke (proposition) is either true or false, in complete independence of any conative activity, whether by God or man. Thus various epistemological notions, such as the correctness of an assertion made, or judgement passed, are reducible to this absolute notion of truth: an assertion (judgement) made (public) through the utterance of a declarative sentence is correct when the proposition expressed by the sentence in question is true. Given this absolute status of truth it is not surprising that Frege is of the opinion that truth is a sui generis notion which has to be left unanalyzed and, indeed, which is indefinable.

It was left to others, in particular Brentano, Russell, and above all, the author of the Tractatus, to provide the desired analysis of truth along the pattern of the truth-maker scheme:

the proposition $\mathrm{A}$ is true

$$
\begin{gathered}
\text { = } \\
\text { there exists a truth-maker for } \mathrm{A} \text {. }
\end{gathered}
$$

One should here, of course, note the obvious historical parallel with Leibniz's Satz vom Grunde: the truth-maker analysis says that whenever a proposition is true, it has a ground, or sufficient reason, namely its truth-maker. The notion of truth thus introduced is obviously dependent both on the chosen category of truth-makers, as well as on the relevant notion of existence for the truth-maker category in question. In the most elaborated of realist truth-maker analyses, namely that offered by Wittgenstein in the Tractatus, the truth-maker for an elementary proposition is a Sachverhalt (state of affairs) and the relevant notion of 
existence is that of Bestehen (obtaining), whereas in the case of non-elementary Sätze the services of truth-makers can be dispensed with, owing to the truth-functional nature of the dependencies on elementary propositions. Other choices were those of Russell, who opted for complexes as truth-makers, and of Brentano, who used judgements as primary truth-bearers and their objects as truth-makers.

Given this variety of options, one cannot expect to be able to make a large number of general claims about the truth-maker analysis. In particular, one should stress that the truth-maker scheme $(*)$ is completely neutral with respect to the properties of truth: whether, for instance, truth is a bivalent notion, will depend on what further properties hold for existence and the relation of truthmaking.

A substantial general point that can be made is the meaning-theoretical observation that when sentence meaning is given in terms of truth conditions, and the latter are provided via the scheme $(*)$, either the notion of existence or the relation of truth-making has to be non-propositional in character, on pain of a vicious infinite regress of ever-descending meaning explanations, much along the same lines as that offered by Frege for truth in Der Gedanke. In the case of Wittgenstein's Tractarian theory, for example, both notions are clearly not propositional: the relation between a(n elementary) proposition and the Sachverhalt it presents is an internal one, and hence can only be shown, but cannot be said, whereas the notion of Bestehen clearly is not expressed by the existential quantifier (which is explained using the truth-condition for an existentially quantified propositional function).

In the proof-theoretical conception of semantics the sort of truth-maker chosen, obviously, is that of proof, so that one can state the truth-maker scheme in the following way:

$$
\begin{gathered}
A \text { is true } \\
=
\end{gathered}
$$

there exists a proof for A.

Both the notion of proof, however, and the concomitant notion of existence, require considerable elaboration in order to get something like a proof-theoretical semantics off the ground.

'Proofs' mainly get spoken about in mathematics, but also in legal contexts: the etymology of the English word proof is different from the word for proofs in other European languages. 'Proof' derives from the Latin verb probare, and sometimes, therefore, means test. The words Beweis (German), bewijs (Dutch), 
bevis (Swedish), démonstration (French), on the other hand, all derive from the same stem as the English demonstration, and philosophically it is often more illuminating to consider the latter word. The OED offers the relevant meaning:

The action or process of demonstrating or making evident by reasoning.

Thus in this sense, proofs are acts, mental acts, as Brouwer rightly held. That through which I get to know something is an act of knowing, a process of knowledge acquisition. Normally one would not apply the notion of existence to an act, so the only reasonable candidate for act-existence seems to be the notion of performance. This, however, would serve to make truth very much a tensed notion: a proposition is true only when it is being proved. The ensuing temporality, however is in flat contradiction with the traditionally recognized atemporality, or 'eternity', of truth. One might try to avoid this uncomfortable conclusion by saying that

a proposition is true when it has been proved,

so that truths once established stay true. Brouwer, indeed, allows for no "nonexperienced" truths. This conception of truth, truth beheld, is still a temporal one, though, of course, temporally stable: prior to a certain moment it has not been proved and thereafter it has been proved. Traditionally, acts are associated with their objects. Proofs are acts of knowing, so the object of a proof act is an object of knowledge, or, in Kantian terminology, an Erkenntnis. On the other hand, an act of getting to know, traditionally, is an act of judgement and its object the judgement made. The word 'theorem' is sometimes reserved for what is proved by an act of mathematical proof. Are the theorems propositions? In one traditional sense they are, and in another modern sense they are not. Traditionally, a proposition is something that is propounded; assertoric force is clearly present. This terminology still survives within mathematics, where theorems are called propositions. In this traditional sense, then, propositions belong on the level of judgements and assertions. Looking at the standard traditional philosophical usage, it appears that 'judgement' and 'proposition' are commonly used for the mental product of the mental act of proof or knowing, whereas 'assertion' seems to be reserved mainly for the outward sign or token used to make public the result of the act. So in one, traditional, sense 'proposition' seems to mean the same as 'judgement', or, if not the same, at least something very closely related to it as an external sign of the mental object of knowledge. ${ }^{1}$

What is the form of a judgement? In the tradition, two-term judgements of the form subject/copula/predicate,

$$
\mathrm{S} \text { is } \mathrm{P} \text {, }
$$

were used. From 1837, that is, from Bolzano onwards, the form 


\section{proposition $\mathrm{A}$ is true}

has become current, and, in particular, it has been considered by Bolzano, Frege, Russell, Wittgenstein, and, through mathematical logic, all of modern analytical philosophy. Bolzano and Frege used Satz an sich and Gedanke, respectively, and the term proposition is Russell's translation of the Fregean Gedanke. Thus propositions are now, in the modern sense, no longer judgements, but judgemental contents.

To sum up: Proofs are acts of knowledge and the object of an act of proof is a judgement made, assertion, theorem (where the terminology depends on what aspects one wants to emphasize). The form of a judgement made is

$$
(* * *) \quad \mathrm{A} \text { is true, }
$$

where $\mathrm{A}$ is a proposition that serves as content of the judgement in question. Application of the truth-maker analysis in terms of proof yields

$$
\text { there exists a proof of } \mathrm{A}
$$

as the form of judgement. This hardly makes sense at this stage, since the proofs we have hitherto considered are acts of proof with judgements as their object. In $(\bullet)$, the proposition $\mathrm{A}$ is not a judgement, but the content of a judgement, and thus not the object of a proof-act: the whole judgement

$$
\text { there exists a proof of } \mathrm{A} \text {, }
$$

when made, rather than merely its content A, has to be the object of a proof-act, whence the formulation $(\bullet)$ appears a category mistake.

Brouwer's view that proofs are mental acts, or constructions, does not provide a suitable truth-maker analysis and it was left to his pupil Arend Heyting to introduce the required notions. He did this as part of decisive contributions to an otherwise confused debate concerning the proper interpretation of the formal calculi that he had introduced in earlier work concerning, for instance, intuitionistic propositional calculus. In other words, Heyting provided an intuitionistic answer to the question

What is a proposition?

just as Frege had provided a classical (realist) answer to the same question. Frege's answer was: a proposition (Gedanke) is a way of presenting one of the 
two truth values The True and The False, or, indeed, a condition determining a truth-value. Heyting, on the other hand, could not use this knowledge-independent notion of truth value and formulated his analysis in terms of proofs and constructions. According to him:

Une proposition $p$, comme, par example, "la constante d'Euler, est rationelle"; exprime un problème, ou mieux encore une certaine attente (celle de trouver deux entiers $a$ et $b$ tels que $C=a / b$ ), qui pourra être réalisée ou déçue. ${ }^{2}[I]$

A year later matters are further clarified:

Ich unterscheide zwischen Aussagen und Sätzen: ein Satz ist die Behauptung einer Aussage. Eine mathematische Aussage drückt eine bestimmte Erwartung aus; [I] z. B. bedeutet die Aussage "die Eulersche Konstante $C$ ist rational" die Erwartung, man könne zwei ganze Zahlen $a$ und $b$ finden, derart, dass $C=a / b$.[III] Vielleicht noch besser als das Wort "Erwartung" drückt das von den Phänomenologen geprägte Wort "Intention" aus, was hier gemeint wird. ...

Die Behauptung einer Aussage bedeutet die Erfüllung der Intention, z. B. würde die Behauptung " $\mathrm{C}$ ist rational" bedeuten, man habe die gesuchten ganzen Zahlen tatsächlich gefunden.[IV] ... Die Behauptung einer Aussage ist selbst nicht wieder eine Aussage, sondern die Feststellung einer . .. Tatsache, nämlich die Erfüllung der durch die Aussage ausgedrückten Intention.[IV] . . .

Ein Problem ist gegeben durch eine Intention, deren Erfüllung gesucht wird.[I] Es ist gelöst, wenn entweder die Intention durch eine Konstruktion erfüllt ist, oder bewiesen ist, dass sie auf einen Widerspruch führt. . . .

Ein Beweis für eine Aussage is eine mathematische Konstruktion, welche selbst wieder mathematisch betrachtet werden kann. ${ }^{3}$ [II] [III]

The final formulation was given in his book Mathematische Grundlagenforschung: Intuitionismus, Beweistheorie: ${ }^{4}$

jede Aussage steht . . . für die Intention auf eine mathematische Konstruktion, die bestimmten Bedingungen genügen soll.[I] Ein Beweis für eine Aussage besteht in der Verwirklichung der in ihr geforderten Konstruktion.[II]

In brief, Heyting's position, as set out in the above quotes, is the following:

I) Mathematical propositions/problems are individuated in terms of what counts as their proofs, that is, the meaning of a mathematical sentence is explained through laying down what is to count as a proof of the proposition expressed by the sentence in question.

II) Proofs of propositions are constructions.

III) Constructions are mathematical objects.

IV) When fully explicit, a mathematical assertion (theorem, judgement) 
takes the form:

Construction $\mathrm{c}$ is a proof of proposition A.

The word 'construction', is of course heavily process/product, act/object ambiguous, between the act of construction and the construction-object constructed in, or through, the act. Furthermore, the construction-procedure, or recipe, according to which the act is carried out is sometimes also known as a construction. Thus 'proof-object' seems an apposite term to apply to the mathematical construction-objects that have to be exhibited in order to have the right to make a mathematical assertion, that is, to judge the truth of a proposition. ${ }^{5}$.

Heyting gave explanations of what one has to know in order to have the right to assert the truth of a proposition. Various formulations have been offered, but the following is fairly standard among versions couched in terms of proofobjects:

(0) No object is a proof of $\perp$.

(i) When a is a proof-object for A and b is a proof-object for B, $<$ a,b $>$ is a proof-object for A\&B.

(ii) When a is a proof-object for A, i(a) is a proof-object for AvB.

When $b$ is a proof-object for $B, j(a)$ is a proof-object for AvB.

(iii) When $b(x)$ is a proof-object for $B$, provided $x$ is a proof-object for $A$, $\lambda \times b(x)$ is a proof-object for $A \supset B$.

(iv) When $P(x)$ is a propositional function over the set $D$ and $b(x)$ is a proofobject for $\mathrm{P}(\mathrm{x})$, provided $\mathrm{x} \in \mathrm{D}$, then $\lambda \mathrm{x} . \mathrm{b}(\mathrm{x})$ is a proof-object for $(\forall \mathrm{x} \in \mathrm{D}) \mathrm{P}(\mathrm{x})$.

(v) When $\mathrm{P}(\mathrm{x})$ is a propositional function over the set $\mathrm{D}, \mathrm{a} \in \mathrm{D}$, and $\mathrm{b}$ is a proofobject for $\mathrm{P}(\mathrm{a}),<\mathrm{a}, \mathrm{b}>$ is a proof-object for $(\exists \mathrm{x} \in \mathrm{D}) \mathrm{P}(\mathrm{x})$.

These formulations are not taken from Heyting, but are inspired by formulations current in the Intuitionistic Type Theory of Per Martin-Löf. ${ }^{6}$ In the sequel, I shall sometimes use

$$
\mathrm{a}: \alpha
$$

as a notation for the assertion (judgement)

a is an object of type $\alpha$.

In particular, when the type in question is that of proof-objects of proposition A, I shall write 


\section{$\mathrm{a}: \mathrm{A}$}

One conceptual refinement is called for at this point: the proof-object introduced in the antecedent clauses of the above explanations are canonical (Dummett), or direct (Gentzen), proofs of the proposition in question. The above direct proof-objects are all of the Gentzen introduction form. It is a commonplace that not all proofs need to be cast in this form; for instance, a proof of a conjunction, the last inference of which is an instance of modus ponens, that is, implication elimination, will obviously not be in introduction form.

The well-known elimination rules provide straightforward examples of ways for obtaining non-canonical proof-objects. Thus, for instance, when $\mathrm{c}$ is a proof-object for $A \& B, p(c)$ is a proof-object for $A$ and $q(c)$ is a proof-object for $B$. The main property of the projections $p$ and $q$ is given by the two evaluation rules

$$
\begin{aligned}
& \mathrm{p}(<\mathrm{a}, \mathrm{b}>)=\mathrm{a}: \mathrm{A} \\
& \mathrm{q}(<\mathrm{a}, \mathrm{b}>)=\mathrm{b}: \mathrm{B} .
\end{aligned}
$$

The distinction between canonical and non-canonical presentations of proof-objects corresponds exactly to the distinction between numerals and other numerical terms: the numerals are canonical presentations in terms of which the set of Natural numbers is introduced. Obviously other ways of presenting objects in this set are also necessary and notations for primitive recursive numerical functions, etc. are introduced, and used to build various numerical terms, where the recursion equations for the functions in question serve to give a notion of definitional equality between the terms. For example, $(3 !+4) / 2$ is a noncanonical (way of presenting a) number. This number can also be given canonically as $5 .^{7}$

In the same way, Prawitz-type reduction steps on proofs provide a notion of equality between canonical and non-canonical proof-objects. ${ }^{8}$ Thus, for instance, by assumption,

\section{$\mathrm{z}: \mathrm{A} \& \mathrm{~B}$, provided $\mathrm{z}: \mathrm{A} \& \mathrm{~B}$.}

Therefore, by \& elimination, $\mathrm{p}(\mathrm{z}): \mathrm{A}$, provided $\mathrm{z}: \mathrm{A} \& \mathrm{~B}$.

Hence, by $\supset$ introduction, $\lambda z p(z)$ is a (canonical) proof-object for $\mathrm{A} \& \mathrm{~B} \supset \mathrm{A}$, now on no assumptions. 
By \& introduction,

$<\lambda \mathrm{zp}(\mathrm{z}), \lambda \mathrm{zp}(\mathrm{z})>:(\mathrm{A} \& \mathrm{~B} \supset \mathrm{A}) \&(\mathrm{~A} \& \mathrm{~B} \supset \mathrm{A})$.

Therefore, by \& elimination,

$\mathrm{q}(<\lambda \mathrm{zp}(\mathrm{z}), \lambda \mathrm{zp}(\mathrm{z})>): \mathrm{A} \& \mathrm{~B} \supset \mathrm{A}$,

which latter non-canonical proof-object, by the second of the two evaluation rules above, that is, one of Prawitz's two \& reduction-steps, is definitionally equal to the canonical proof-object $\lambda z p(z): A \& B \supset A$.

Dummett has emphasized that this distinction between canonical and noncanonical proofs of propositions is needed also in order to resolve the "paradox of inference," that is, in order to be able to account for the validity as well as the epistemological usefulness of logic as a tool of reasoning. ${ }^{9}$ The epistemological usefulness of logic arises from the fact that logical inference provides other means than the directly meaning-given means for verifying the truth of a proposition. For instance, the direct, meaning-given means of getting to know the truth of the proposition

Göran Sundholm has got six florins in his pocket

is to count, but one could also find out the truth of this through a chain of inferences; I began the day with, say, a $25 \mathrm{fl}$. note, have made such and such purchases, totalling, by the rules of arithmetic, such and such a sum, each time receiving such and such change, where the only possible distribution, given the Dutch coinage, contains six coins of worth one guilder. Logic is epistemically useful because it provides indirect means for recognizing the truth of a proposition over and above the directly meaning-given means.

If meaning is given in terms of proofs, that is, means of coming to know the truth of the sentence in question, then clearly, the meaning-giving means are included in the meaning-given means for coming to know the truth. Furthermore, the meaning-given means then seem to encompass all the means there are for the recognition of truth. The required gap between direct, meaninggiven, and indirect, logical means is then closed. The distinction between canonical proof-objects, in terms of which meaning is given, and other, non-canonical proof-objects, allows us to hold this gap open.

On this intuitionistic meaning-analysis the truth-maker is a mathematical 
construction-object and the relation of truth-making is that of the construction's being a proof-object for the proposition in question. The relevant notion of existence still remains to be dealt with. When $\alpha$ is a general concept (type, sort, category, etc.), so that

$$
\mathrm{a}: \alpha
$$

is a form of judgement, one can introduce yet another form of judgement, namely

\section{$\alpha$ EXISTS.}

In general, in order to explain a form of judgement, one has to lay down what one has to know in order to make a judgement of the form in question. The required knowledge in the present case is that one has to know some particular judgement of the form

$$
\mathrm{a}: \alpha \text {. }
$$

that is, the rule

$$
\frac{\mathrm{a}: \alpha}{\alpha \text { EXISTS }}
$$

provides the only way of asserting the judgement $\alpha$ EXISTS..$^{10}$

One should stress that it is only here, at this late stage, that the logic of proof-theoretical semantics becomes intuitionistic: owing to the use of this judgemental notion of EXISTENCE, we are not able to assert the Law of Bivalence. The proof-theoretical semantics itself, that is, the proof-object clauses given, are perfectly neutral with respect to the properties of the notion of truth, just in the same way that the Tarski T-sentences are completely neutral with respect to classical versus intuitionistic logic. ${ }^{11}$ Indeed, as Troelstra and van Dalen observe, using enough classical reasoning, and a classical notion of existence, the proposition $\mathrm{A}$ becomes equivalent to the existence of a proof-object for $\mathrm{A}$, and thus the semantics in itself

has no "explanatory power": the possibility of recognizing a classically valid schema as being constructively unacceptable depends entirely on our interpretation of "construction", "function", "operation". 12

Using the notion of EXISTENCE we see that on the intuitionistic analysis 
the Bolzano form of judgement

$A$ is true

is brought back to, or is a special case of, the traditional form of judgement

$\mathrm{S}$ is $\mathrm{P}$

in the form of

$\mathrm{a}: \mathrm{A}$,

through the use of the intermediary form

\section{A EXISTS. ${ }^{13}$}

Returning once more to the act/object terminology, we can now see that the object of an act of proof is not a proof-object, but the judgement proved. The proof-object, or construction-object, on the other hand, is the object of an act of construction. ${ }^{14}$

The notion of identity for propositions is notoriously a difficult one: Quine, indeed, has based his rejection of analyticity, modality, and second-order quantification, on the lack of a viable criterion of identity for propositions. "No entity without identity" is the slogan offered here. Frege continued to address this issue from his very first philosophical writings onwards. In the Begriffsschrift, $\$ 3$, he observes that Inhalte (contents) of judgements, that is, propositions, can differ in two ways:

erstens so, dass die Folgerungen, die aus einem in Verbindung mit bestimmten anderen gezogen werden können, immer auch aus dem zweiten in Verbindung mit denselben anderen Urtheilen folgen; zweitens so, dass dies nicht der Fall ist. ...

Ich nenne nun denjenigen Theil des Inhaltes, der [in der ersten Weise] in beiden derselbe ist, den begrifflichen Inhalt. Da nur dieser für die Begriffsschrift von Bedeutung ist, so braucht sie keinen Unterschied zwischen Sätzen zu machen, die denselben begrifflichen Inhalt haben.

The relevant inference condition between equal judgemental contents $\mathrm{A}$ and $\mathrm{B}$ is thus the following: every judgement $\mathrm{J}$ that can be inferred from the judgements $\mathrm{J}_{1}, \ldots, \mathrm{J}_{\mathrm{k}}$ and the judgement that ascribes truth to the content $\mathrm{A}$, can also be inferred from the judgements $\mathrm{J}_{1}, \ldots, \mathrm{J}_{\mathrm{k}}$ and the judgement that ascribes truth to 
the content $\mathrm{B}$, and vice versa. At the conclusion of my analysis I shall return to this formulation, but for the moment I confine myself to the observation that the criterion for the identity of contents is given through consideration of what epistemic attitudes have to be taken towards certain contents, given that certain attitudes have already been adopted towards certain other contents.

It is interesting to note that according to his own outline, Frege's first attempted Logik halts precisely at the point where the beurteilbare Inhalte, that is, propositional contents of judgements, should have been brought in connection with Schlüsse, that is, at the precise point where one could expect a detailed treatment of the above summary Begriffsschrift-criterion for the identity of propositions. ${ }^{15}$

In Über Sinn und Bedeutung a criterion for sameness of sentential sense, that is, for sameness of thoughts expressed, is offered in terms of cognitive equipollency:

Ersetzen wir nun [im Satze] ein Wort durch ein anderes von derselben Bedeutung, aber anderen Sinne, so kann dies auf die Bedeutung des Satzes keinen Einfluss haben. Nun sehen wir aber, dass der Gedanke sich in solchem Falle ändert; denn es ist z. B. der Gedanke des Satzes "der Morgenstern ist ein von der Sonne beleuchteter Körper" verschieden von dem des Satzes "der Abendstern ist ein von der Sonne beleuchteter Körper". Jemand, der nicht wüsste, dass der Abendstern der Morgenstern ist, könnte den einen Gedanken für wahr, den anderen für falsch halten. ${ }^{16}$

Two propositions are, accordingly, different when it is possible to hold different epistemic attitudes towards them. In other words, two propositions are equal if it is not possible to hold one true and the other false, that is, if one holds the one true, one also must hold the other one true, and vice versa. Thus, also this Fregean formulation of propositional identity is yet again cast in terms of the necessity to adopt equal epistemic attitudes towards both contents.

In 1897, in the course of his second attempt at a Logik, Frege returns to the issue and offers the following:

Die Sätze "M gab dem $N$ die Urkunde A", "die Urkunde A wurde von M dem N gegeben", "N empfing von $\mathrm{M}$ die Urkunde A" drücken genau denselben Gedanken aus; man erfährt durch keinen dieser Sätze das geringste mehr oder weniger als durch die anderen. Daher is es auch unmöglich, dass einer von ihnen richtig und zugleich ein anderer falsch sei....

Auch in den beiden sätzen "Friedrich der Grosse siegte bei Rossbach" und "es ist wahr, dass Friedrich der Grosse bei Rossbach siegte" haben wir denselben Gedanken bei verschiedener sprachlicher Form, wie schon oben gesagt worden ist. Indem wir den Gedanken des ersten Satzes bejahen, bejahen wir mit derselben Tat auch den Gedanken des zweiten und umgekehrt. Es sind nicht zwei verschiedene Urteilstaten, 
sondern nur eine. ${ }^{17}$

Again, two thoughts are held to be equal when an affirmation of the one, eo ipso, is an affirmation of the other, and vice versa. Indeed, as Frege rightly notes, in such a case one does not get to know anything more, or less, from one, rather than the other.

In August, 1906, Frege returns once more to the difficult task of providing an Einleitung in die Logik. He begins his treatment of Gedanken without pausing for a criterion of identity and carries it through a number of relevant topics that are dealt with within a week according to the given dates. Shortly afterwards Husserl and Frege conduct an exchange by mail on the notion of propositional identity. The occasion is a survey article by Husserl on recent German work in logic and, in particular, the report there on an article by Marty. ${ }^{18}$ Husserl made a distinction between 'congruent' and 'equipollent' declarative sentences, where congruence seems to mean syntactical identity and 'equipollence' cognitive equivalence. In the first letter under discussion, of ' 30.10 bis 1.XI. 1906', Frege simply uses the notion of equipollence without further ado:

Man muss sich in der Logik dazu entschliessen, äquipollente Sätze als nur der Form nach verschieden zu betrachten. Äquipollente Sätze haben, nachdem die behauptende Kraft, mit der sie etwa ausgesprochen sind, abgezogen ist, etwas gemeinsames im Inhalte, und dies nenne ich den von ihnen ausgedrückten Gedanke. Dieser kommt für die Logik allein in Betracht.

Furthermore he discusses the possibility of logical analyses and tries to convince Husserl that two particular sentences are equipollent on Husserl's reading of equipollence. The latter holds that equipollence means that the negations of the sentences in question have to be equivalent (gleichwertig). Frege tries to establish this using his truth-value analysis. In the course of so doing he remarks that his Begriffsschrift and its truth-table explanations are now 28 years old. This remark he repeats from the August notes towards an Introductory Logic and shows that the Husserl correspondence may be seen in connection with the Logic. ${ }^{19}$ This impression is strengthened further through the occurrence in the letter of many of the same themes as in the notes, for instance, force, colouring, etc. A bipartite reply, XIX/4-5, of 10.11 and 16.11, 1906, from Husserl to Frege, is lost, but Husserl did comment on, among other matters, equipollent sentences. ${ }^{20}$ Frege, who had terminated his letter $\mathrm{XIX} / 3$ with:

Ich sehe wenigstens nicht, welches Kriterium da objektiv die Entscheidung geben sollte.

Ich finde aber, dass eine Frage, für deren Beantwortung es kein objektives Kriterium 
gibt, überhaupt in der Wissenschaft keine Stelle hat,

clearly remained unsatisfied with what had been said until then concerning the criterion for propositional identity, and having been able to draw breath for five weeks since his previous letter, comes back for a second round:

Es scheint mir ein objektive Kriterium notwendig zu sein, um einen Gedanken als denselben wiederzuerkennen, weil ohne ein solches eine logische Analyse nicht möglich ist. Um nun zu entscheiden, ob der Satz A denselben Gedanken ausdrücke wie der Satz B, scheint mir folgendes Mittel allein möglich zu sein, wobei ich annehme, dass keiner der beiden sätze einen logisch evidenten Sinnbestandteil enthalte. Wenn nämlich sowohl die Annahme, dass der Inhalt von A falsch und der von B wahr sei, als auch der Inhalt von A wahr und der von B fasch sei, auf einen logischen Widerspruch führt, ohne dass man $\mathrm{zu}$ dessen Feststellung $\mathrm{zu}$ wissen braucht, ob der Inhalt von A oder der von B wahr oder falsch sei, und ohne dass man dazu andere als rein logischer Gesetze bedarf, so kann zum Inhalte von A, soweit er fähig ist, als wahr oder falsch beurteilt zu werden, nichts gehören, was nicht auch zum Inhalte von B gehörte; denn füre inen solchen Überschuss fehlte es an jeder Begründung im Inhalte von B, und der Voraussetzung nach wäre ein solcher Überschuss auch nicht logisch evident. Ebenso kann bei unserer Annahme zum Inhalte von B, soweit er fähig ist, als wahr oder falsch beurteilt zu werden, nichts gehören, was nicht auch zum Inhalte von A gehörte. Was also an den Inhalten von A und B als wahr oder falsch beurteilbar ist stimmt überein, und dies kommt für die Logik allein in Betracht, und das nenne ich den von A ebenso wie von B ausgedrückten Gedanken.

Hardly an easy criterion to apply or even to understand! Again the criterion is given in terms of passages from an ascription (Annahme) of truth to one content to the ascription of truth to another, and vice versa. The danger with this type of criterion is that perhaps it will yield nothing more strict than the truth or logical truth of the material equivalence between the two propositions in question. All the extra paraphernalia concerning no logically evident meaning-determining parts, and so on, are superimposed to take this worry into account. Furthermore, it should be remarked that all the criteria considered, or, perhaps better, all of Frege's attempts at a criterion, are aimed at sentences in oratio recta: the problems of indirect discourse are, indeed, better left out of the discussion at this stage.

Whether it is adequate or not, the criterion from the second letter to Husserl is unsatisfactory, owing simply to its sheer complexity. It does not seem unlikely that Frege shared this feeling, since upon reflection he returned to the matter in the revisions he made to the early parts of the Einleitung in die Logik in his Kurze Übersicht meiner logischen Lehren. ${ }^{21}$ The opening passage is amplified and does now contain a simple, straightforward and elegant criterion for the equipollence of sentences, that is, for the identity of propositions: 
Zwei Sätze A und B können nun in der Beziehung stehen, dass jeder, der den Inhalt von $A$ als wahr anerkennt, auch den von $B$ ohne weiteres als wahr anerkennen muss, und dass auch umgekehrt jeder, der den Inhalt von B anerkennt, auch den von A unmittelbar anerkennen muss (Äquipollenz), wobei vorausgesetzt wird, dass die Auffassung der Inhalte von A und B keine Schwierigkeiten macht.

So when the meanings of A and B are grasped, the criterion for equipollence is that the inference from the judgement

A is true

to the judgement

$\mathrm{B}$ is true

is an immediate one, and vice versa. This, I think, is the ultimate formulation of the criterion for which Frege has been grasping throughout his long search. It is, of course, very much cast in the same mould as its predecessors, relying, as it does, on a relation of passage between ascriptions of truth to relevant contents, but the simplicity of the extra condition, namely the immediacy of the inference, is most compelling. The pellucid character of this formulation certainly compares favourably with the earlier efforts and it appears that Frege himself was also not unsatisfied, since he did not return to the issue in later writings.

Using the proof-theoretical semantics the matter can be simplified even further. You explain a proposition (intention, problem) by laying down how a canonical proof-object may be formed. Furthermore, one must explain when two canonical proof-objects are equal proofs of the proposition in question. Given this explanation of what a proposition is, it is now very easy to explain propositional equality:

$\mathrm{A}$ and $\mathrm{B}$ are equal propositions when every canonical proof-object of $\mathrm{A}$ is a canonical proof-object of $\mathrm{B}$, and vice versa (and equal canonical proof-objects of $\mathrm{A}$ are equal canonical proof-objects for $\mathrm{B}$, and vice versa).

This means that the immediacy in Frege's criterion can be explained a little bit further; for equal propositions $\mathrm{A}$ and $\mathrm{B}$ the following rules hold 
$\frac{\mathrm{a}: \mathrm{A}}{\mathrm{a}: \mathrm{B}}$ and $\frac{\mathrm{b}: \mathrm{B}}{\mathrm{b}: \mathrm{A}}$

as well as the corresponding rules for $\mathrm{a}=\mathrm{b}: \mathrm{A}$. With propositions that are merely equivalent, it must be so that a proof-object $\mathrm{b}: \mathrm{B}$ exists, given that a proofobject a : A exists, and vice versa. This does not demand that every proof-object for $\mathrm{A}$ has to be one for $\mathrm{B}$, and vice versa; what is required is only that two functions $f$ and $g$ exist, such that

$$
f(x): B \text {, provided } x: A \text {, }
$$

and

$$
\mathrm{g}(\mathrm{y}): \text { A, provided } \mathrm{y}: \mathrm{B} \text {. }
$$

The functions $\mathrm{f}$ and $\mathrm{g}$ allow one to assert the implications in each direction, and hence the truth of the equivalence $A \leftrightarrow B$ is assured.

When, on the other hand, two propositions A and B are equal, as soon as the judgement

$$
\mathrm{a}: \mathrm{A}
$$

has been made, one can immediately make the judgement

$$
\mathrm{a}: \mathrm{B} \text {, }
$$

and, of course, vice versa. For propositions such that

$$
\mathrm{A} \leftrightarrow \mathrm{B} \text { is true, }
$$

as soon as the judgement

$$
\mathrm{a}: \mathrm{A}
$$

has been made, one can make the judgement

$$
\mathrm{B} \text { is true, }
$$

owing to the function $\mathrm{f}$ that transforms a into 


$$
\text { f(a) : B , }
$$

but, in general, there is no guarantee whatever that the judgement

$$
\text { a : B }
$$

can be made.

Above the promise was made to return to the attempted Begriffsschrift criterion. The problem concerning this formulation is that when only judgements of the truncated form

\section{$A$ is true}

are considered, the criterion of propositional equivalence seems fulfilled by any two equivalent propositions A and B. Suppose that

C is true

can be inferred from the three assumptions

$\mathrm{A}$ is true, $\mathrm{D}$ is true and $\mathrm{E}$ is true.

Then, surely, it can also be inferred from

$\mathrm{B}$ is true, $\mathrm{D}$ is true and $\mathrm{E}$ is true

in the following way:

assume B is true.

But $\mathrm{A}$ and $\mathrm{B}$ are equivalent, therefore

$A$ is true.

But

$\mathrm{C}$ is true 
can be inferred form

$\mathrm{A}$ is true, $\mathrm{D}$ is true and $\mathrm{E}$ is true.

Therefore it can also be inferred from

$\mathrm{B}$ is true, $\mathrm{D}$ is true and $\mathrm{E}$ is true,

and similarly for the opposite direction. ${ }^{22}$ The inference condition applies, whence the propositions are equal. Thus the Begriffsschrift criterion for propositional equality does seem to force identity onto equivalent propositions, and this is hardly satisfactory.

When we enlarge our judgements to include also the proof-objects, the above reasoning is no longer possible. In fact, assume that the inference condition holds between the judgmental contents A and B. I shall then show that A and $B$ are equal propositions. Naturally from the judgement

$$
\mathrm{a}: \mathrm{B}
$$

one can obviously infer the judgement

$$
\mathrm{a}: \mathrm{B} \text {, }
$$

where the permitted extra premises can even be dispensed with. But since the inference condition holds between contents $\mathrm{A}$ and $\mathrm{B}$, from the judgement

$$
\text { a : A }
$$

one can then also infer

$$
\mathrm{a}: \mathrm{B} \text {, }
$$

and similarly for the opposite direction. Thus the propositions are equal. ${ }^{23}$

It should be stressed, though, that Frege clearly intended his criterion to be universally applicable also outside of mathematics. The proof-theoretical semantics has only been provided for the language of mathematics and it is still an open question of how best to extend it to other areas of discourse. In particular, what is the ontological status of (what has to serve as) proof-objects in the case of proof-acts of perception? This, and other equally hard questions, are still in want 
of a treatment.

In this paper I have only attempted to give one application of the proof-theoretical semantics in order to illuminate a point form the philosophy of logic, namely, the question of identity between propositions. A number of such applications have already been given. The problem of Donkey-sentences was dealt with directly using the type theoretical abstractions in a straightforward way by Martin-Löf, and, with another later treatment, also by myself. ${ }^{24}$ Aarne Ranta has made impressive progress in the systematic application of Martin-Löf's type theory to linguistics. ${ }^{25}$ A number of philosophical topics has also been dealt with. Martin-Löf has treated of the notions of truth and analytic judgements. ${ }^{26}$ Petri Mäenpää has dealt with the method of analysis and synthesis, whereas I have considered some themes from the philosophy of mathematics. ${ }^{27}$ Thus, enough seems to have been accomplished in order to render a favourable judgement as to the interest and viability of the proof-theoretical approach to semantics.

Leiden University,

Göran Sundholm

The Netherlands

\section{NOTES}

* I am indebted to Per Martin-Löf for many conversations that have considerably helped to shape the views reported herein, as well as for detailed comments on the draft text, and to my colleague Dr. M. S. van der Schaar for having drawn my attention to Frege's checkered search for an identity criterion with respect to Gedanken. A fuller statement of some of the points regarding Heyting's work can be found in my "Constructions, Proofs and the Meaning of the Logical Constants," Journal of Philosophical Logic 12(1983), pp. 151-72. All translations are my own.

1. A rather detailed treatment of the matters dealt with in the present section can be found in the First lecture of Per Martin-Löf's "On the Meanings of the Logical Constants and the Justifications of the Logical Laws," in: Atti degli incontri di logica matematica, vol 2, pp. 203-81, Scuola di Specializzazione in Logica Matematica, Dipartimento di Matematica, Università di Siena 1985 (Notes from lectures delivered in 1983).

2. "Sur la logique intuitionniste," Académie Royale Belgique, Bull. Cl. Sci., V, 16, pp. 957-63, in particular p. 958. English translation:

A proposition $p$, for example, 'Euler's constant $C$ is rational' expresses a problem, or better still, a certain expectation (that of finding two integers $a$ and $b$ such that $C=a / b$ ) that can be realized or disappointed.

The bracketed Roman numerals in connection with this and the following two quotes serve to substantiate the points [I]-[IV] below. 
3. "Die intuitionistische Grundlegung der Mathematik," Erkenntnis 2 (91931), pp. 106-15, in particular, 113-14. English translation:

I distinguish between propositions and assertions: an assertion is the affirmation of a proposition. A mathematical proposition expresses a certain expectation; the proposition "Euler's constant $\mathrm{C}$ is rational," for instance, expresses the expectation that one could find two integers $a$ and $b$ such that $C=a / b$. The word "Intention", that was coined by the phenomenologists, does, perhaps even better than the word "expectation", express what is meant here.... The affirmation of a proposition means the fulfillment of the Intention, for instance, the affirmation " $\mathrm{C}$ is rational" would mean that one had indeed found the required integers. ... The affirmation of a proposition is not itself a proposition, but the positing of a . . fact, namely the fulfillment of the Intention expressed by the proposition. ... A problem is given by an Intention whose solution is sought. It is solved when either the Intention is fulfilled by a construction or it is proved that it leads to a contradiction. ... A proof of a proposition is a mathematical construction, which can itself be reflected upon mathematically.

\section{Julius Springer, Berlin, 1934, p. 14. English translation:}

Every proposition stands for an Intention towards a mathematical construction that satisfies certain conditions. The proof of a proposition consists in the actualization of the construction it requires.

5. As far as I know this convenient 'proof-object' terminology was first introduced in J. Diller and A. S. Troelstra, "Realizability and Intuitionistic Logic," Synthese 60 (1984), pp. 253-82.

6. See his book of that title, Bibliopolis, Naples, 1984, and B. Nordström, K. Petterson and J. Smith, Programming in Martin-Löf's Type Theory, Oxford University Press 1990.

7. I have here considered the Arabic numerals canonical terms for Natural numbers. In formal systems, such as the type theory of Martin-Löf, the canonical numerical terms are usually built up from 0 and the successor function $\mathrm{s}$. The treatment offered of 'präsentierende singuläre Terme' (that correspond to canonical names in my terminology) in Wolgang Künne, Abstrakte Gegenstände (Frankfurt am Main: Suhrkamp, 1983), ch. 4, §7, is most illuminating here.

8. D. Prawitz, Natural Deduction, Almquist \& Wiksell, Stockholm, 1965.

9. See M.A.E. Dummett, "The Justification of Deduction," Proceedings of the British Academy, LIX (1973), pp. 1-34. See also my "Proof Theory and Meaning," in D. Gabbay and F. Guenthner (eds.), Handbook of Philosophical Logic, vol. III (Dordrecht: Reidel, 1986), ch. III:8, especially pp. $486-89$, where the matter is dealt with in some detail.

10. The form of judgement $\alpha$ EXISTS was introduced by Martin-Löf in his paper "Analytic and Synthetic Judgements in Type Theory," in the proceedings of the Workshop on Kant and Contemporary Philosophy (Florence, 27-30 May, 1992).

11. This neutrality of the proof-clauses is, of course, nothing but the neutrality of the truth-maker scheme $\left(^{*}\right)$ that was already commented upon above.

12. Constructivism in Mathematics, vol. 1 (Amsterdam: North-Holland, 1988), exercise 1.3.4., pp. 32-33. 
13. Here I choose to view the proposition as a type of proof-objects. One could also introduce the type

proof(A)

of proofs of the proposition $\mathrm{A}$ and then

$A$ is true

$=$

Proof(A) EXISTS.

The differences here are, however, mainly terminological.

14. A number of issues concerning the ambiguity of 'proof' and 'construction' are dealt with in my paper "Questions of Proof," Manuscrito, special issue on the Philosophy of Mathematics, October 1993.

15. See the fragment Logik, Nachgelassene Schriften, 2nd ed. (Hamburg: Felix Meiner, 1983), pp. 1-9. English translation: Posthumous Writings (Oxford: Basil Blackwell, 1979), pp. 1-9.

16. Zeitschrift für Philosophie und philosophische Kritik, NF 100 (1892), pp. 25-50, in particular p. 32.

17. Logik (1897), NS, footnote 15, p. 153, (PW, p. 141).

18. The relevant bibliographical material can be found in editorial apparatus provided in Gottlob Frege, Wissenschaftlicher Briefwechsel, Gottfried Gabriel, Hans Hermes, Friedrich Kambartel, Christian Thiel, and Albert Veraart (eds.) (Hamburg: Felix Meiner Verlag, 1976), letters XIX/3 and XIX/6, pp. 101-06.

19. NS, p. 202 (PW, p. 186). WB, p.104.

20. The remark by the editors of $W B$ that Husserl's comments on 'Paradoxie' in XIX/5 could concern Russell's paradox, I consider implausible. Indeed, in his comments on Marty in the survey article that was the cause of the discussion with Frege, Husserl does remark on a paradox which is directly related to his notion of equipollency and to the equipollence that Frege had attempted to demonstrate. To my mind, it seems much more likely that he continued to discuss this theme, rather than to deviate into a discussion of Russell's paradox, a topic not at all germane to what had been dealt with in the rest of this exchange between Frege and Husserl.

21. NS, pp. 213-18, especially p. 213 ( $P W$ p. 197).

22. I have here taken Frege's word 'Folgerung' in the sense of what can be mediately inferred from. If 'folgern' should be read as 'immediately infer', the Begriffsschrift criterion turns out to be but a variant of the final 1906 (?) criterion.

23. Strictly speaking, I should here also consider judgements of the form $\mathrm{a}=\mathrm{b}: \mathrm{A}$,

but the reasoning is entirely analogous.

24. Martin-Löf's treatment, given, en passant and informally, during the meeting on Konstruktive Mengenlehre und Typentheorie at Munich, October 1980, was never published. My own independent treatment was given, also en passant, at a meeting of Handbook authors at Bad Homburg, November 1981, and published in "Proof Theory and Meaning," $\S 7$, cited in $n .9$ above. For both treatments, see my "Constructive Generalized Quantifiers," Synthese 79 (1989), pp. 1-12, esp. p. 8. 
25. "Propositions as Games as Types," Synthese 76 (1988), pp. 377-95, "Intuitionistic Categorical Grammar," Linguistics and Philosophy 14 (1991), pp. 203-39, and his Type-Theoretical Grammar, forthcoming (Cambridge: Cambridge University Press, 1994).

26. In "A Path from Logic to Metaphysics," in G. Corsi and G. Sambin (eds.), Atti del congresso Nuovi Problemi della Logica e della Filosofia della Scienza, Viareggio, 8-13 gennaio, 1990 (CLUEB, Bologna, 1991), pp. 141-49, and in the paper cited in n. 10 above.

27. In his doctoral dissertation The Art of Analysis: Logic and History of Problem Solving (Helsinki: University of Helsinki, 1993), respectively in my papers "Constructions. ...," cited in * above, and "Questions of Proof," cited in n. 14. 